\title{
Antimicrobial activity of the ethanol extract of the aerial parts of sida acuta burm.f. (malvaceae)
}

\author{
IE Oboh ${ }^{1}$, JO Akerele ${ }^{2 \star}$ and O Obasuyi ${ }^{2}$ \\ ${ }^{1}$ Department of Pharmacognosy, University of Benin ,Benin City, Nigeria \\ ${ }^{2}$ Department of Pharmaceutical Microbiology, University of Benin ,Benin City, Nigeria.
}

\begin{abstract}
Purpose: The antimicrobial activity of the $90 \%$ ethanol extract of the aerial parts of Sida acuta Burm. F. (Malvaceae) was investigated in other to verify its claimed ethno medicinal use in the treatment of microbial infections.

Method: The antimicrobial activity of the extract was tested against standard strains and clinical isolates of some aerobic bacteria and a fungus using the Agar well diffusion method. Commercial antibiotics were used as positive reference standards to determine the sensitivity of the strains.

Results: The extracts showed significant inhibitory activity against standard strains and clinical isolates of Staphylococcus aureus, clinical isolates of Bacillus subtilis and Streptococcus faecalis. The MIC values obtained using the Agar-dilution test ranged from $5.0 \mathrm{mg} / \mathrm{ml}$. - $10.0 \mathrm{mg} / \mathrm{ml}$. Neither the concentrated extract nor its dilutions inhibited Esherichia coli, Klebsiella pneumonia, Pseudomonas aeruginosa and Candida albicans

Conclusion: The results demonstrate that the crude extract of the aerial parts of Sida acuta has a narrow spectrum of activity and suggest that it may be useful in the treatment of infections caused by Gram positive aerobic bacteria.
\end{abstract}

Key words: Sida acuta, ethanol extract, antimicrobial activity.

*Corresponding Author: E-mail: akerelej@uniben.edu 


\section{INTRODUCTION}

Sida acuta Burm F. (Malvaceae) is an erect, branched small perennial herb or small shrub which grows abundantly on cultivated fields, waste areas, roadsides and open clearing in Nigeria ${ }^{1}$.

The plant has a variety of traditional uses. The hot water extract of the dried entire plant is administered orally in India as a febrifuge, an abortifacient and a diuretic ${ }^{2}$. In Papua New Guinea, the fresh root is chewed for the treatment of dysentery ${ }^{3}$.The leaf juice is also used in India for vomiting and gastric disorders ${ }^{4}$.In Nicaragua, the decoction of the entire plant is taken orally for asthma, fever, aches and pains, ulcers and as an anti-worm medication; while a decoction of the dried entire plant is taken orally for venereal diseases ${ }^{5,6}$.

The antibacterial activity of the chloroform extract of the dried leaf of Sida acuta on Mycobacterium smegmatis has been reported ${ }^{7}$. The antibacterial activity of the steroidal fraction against Escherichia coli, Klebsiella species, Proteaus vulgaris, Pseudomonas pyocyanae and Staphylococcus albus was reported ${ }^{8}$. The antibacterial activity of its seed extract on Escherichia coli, Pseudomonas circhorii, and Salmonella tyhimurium has also been reported ${ }^{9}$.The antibacterial activity of the alkaloids from Sida acuta was recently reported ${ }^{10}$.

This present study examined the activity of the $90 \%$ ethanol extract of the aerial parts of Sida acuta against some aerobic bacteria and a fungus.

\section{MATERIALS AND METHODS Plant material}

The aerial parts of Sida acuta were collected in June 2006, at Ikpoba hill Benin City.Edo State, Nigeria. The plant was authenticated by Dr. Edewor and Mr. Usang Felix of the Forestry Research Institute of Nigeria, Ibadan, where a herbarium voucher specimen (FHI No.107151) was deposited.

The plant material was air-dried on the laboratory bench for 5 days and then ground to powder using an electric mill. $450 \mathrm{~g}$ of the powdered aerial parts of the plant material was macerated with $2800 \mathrm{ml}$ of $90 \%$ ethanol for 72 hours. The extract was filtered and concentrated to dryness by evaporation in a vacuum rotavapour at $40{ }^{\circ} \mathrm{C}$ to yield $16.94 \mathrm{~g}$ of the crude ethanol extract, which was used for the antimicrobial tests.

\section{Test organisms}

The following microorganisms were used for the study. Standard strain of Staphylococcus aureus (NCTC 10788) and clinical isolates of Staphylococcus aureus, Bacillus subtilis, Streptococcus faecalis, Esherichia coli, Klebsiella pneumoniae, Pseudomonas aeruginosa and Candida albicans. These microorganisms were obtained from the laboratory stock of the Department of Pharmaceutical Microbiology, University of Benin, Benin City, Nigeria. They were maintained on agar slants at $4^{\circ} \mathrm{C}$ in the refrigerator.

\section{Drugs and Microbiological Media}

The antimicrobial agents used were: amoxicillin (Smithkline Beecham Pharmaceuticals, U.K); ciprofloxacin (Ranbaxy Pharmaceuticals India); fluconazole( Greenlife; pharmaceuticals India); nutrient broth and nutrient Agar (Oxiod Ltd, Basingtone, Hampshire, England) and Sabouraud Dextrose Agar (4\% GlucoseAgar Fluka Chemie GmBH CH-9471 Backs)

\section{Preparation of plates for susceptibility tests}

The agar-well diffusion method, suitably modified was adopted for the susceptibility studies ${ }^{11,12,13}$. Inocula of the test organisms obtained were prepared by growing each pure isolate in nutrient broth overnight $37 \mathrm{o} \mathrm{C}$.The overnight broth culture was, subcultured in fresh nutrient broth and grown for 3 hours, to obtain log phase culture. This was matched with MacFarland's turbidity standard to give approximately $10^{8}$ $\mathrm{cfu} / \mathrm{ml}$. Aliquots of $0.2 \mathrm{ml}$ was used to seed a molten nutrient agar medium, which was cooled to $45^{\circ} \mathrm{C}$ to obtain approximately $10^{6} \mathrm{cfu} / \mathrm{ml}$. This was poured unto the sterile Petri dishes and used for the investigations. Candadia albicans was grown on sabouraud $4 \%$ glucose agar and 
Table1: In vitro antimicrobial activity of $25 \mathrm{mg} / \mathrm{ml}$ of the ethanol extract of the aerial parts of Sida acuta.

\begin{tabular}{|c|c|c|c|c|c|}
\hline \multirow[t]{2}{*}{ Organisms } & \multicolumn{4}{|c|}{${ }^{*}$ Mean diameter of zone of inhibition } & \multirow[b]{2}{*}{$\begin{array}{l}\text { Sterile } \\
\text { Distilled Water) }\end{array}$} \\
\hline & $\begin{array}{c}\text { S. acuta } \\
(25 \mathrm{mg} / \mathrm{ml})\end{array}$ & $\begin{array}{c}\text { CIP. } \\
(5 \mu \mathrm{g} / \mathrm{ml})\end{array}$ & $\begin{array}{c}\text { AMX. } \\
(25 \mu \mathrm{g} / \mathrm{ml})\end{array}$ & $\begin{array}{l}\text { FLU. } \\
(20 \mu \mathrm{g} / \mathrm{ml})\end{array}$ & \\
\hline \multicolumn{6}{|l|}{ Bacteria } \\
\hline Staphylococcus aureus & 21.3 & 26.0 & 15.3 & N.D & - \\
\hline Staphylococcus aureus $\quad$ (NCTC 10788) & 16.0 & 34.0 & 23.0 & N.D & - \\
\hline Streptococcus faecailis & 14.0 & 19.0 & 16.0 & N.D & - \\
\hline Bacillus subtilis & 16.0 & 19.8 & 18.0 & N.D & - \\
\hline Klebsiella pneumonia & _ & 27.0 & - & & - \\
\hline Pseudomonas aeruginosae & _- & 19.5 & & & - \\
\hline $\begin{array}{l}\text { Esherichia coli } \\
\text { Fungi }\end{array}$ & - & 26.5 & 16.5 & & - \\
\hline Candida albicans & - & N.D & N.D & 35.0 & - \\
\hline
\end{tabular}

* = Mean of 3 determinations; - = No inhibition; Zones measuring $>12 \mathrm{~mm}$ were acceptable as sensitive; $N D=N o t$ determined, since fluconazole has no antibacterial activity; $C I P=$ Ciprofloxacin; $A M X=A m o x y c i l l i n ; F L U=$ Fluconazole; SDW = Sterile Distilled water.

suspension in $1 / 4$ strength Ringers solution was used to prepare the seeded Sabourand $4 \%$ Dextrose agar plates. The crude extract was reconstituted with sterile distilled water and stock concentration of $1 \mathrm{~g} / \mathrm{ml}$ or $1000 \mathrm{mg} / \mathrm{ml}$ was made. The extract was tested at a concentration of 25 $\mathrm{mg} / \mathrm{ml} .200 \mu \mathrm{l}$ of this concentration was delivered into wells (8 $\mathrm{mm}$ in diameter) bored unto the already seeded nutrient agar plates. Equal volume of distilled water was assayed as control. Ciprofloxacin $(5 \mu \mathrm{g} / \mathrm{ml})$, amoxycillin $(25 \mu \mathrm{g} / \mathrm{ml})$ and fluconazole $(20 \mu \mathrm{g} / \mathrm{ml})$ were included as standard antimicrobial agents and tested along with the extract. The nutrient agar plates were incubated at $37^{\circ} \mathrm{C}$ for 24 hours while the sabouraud agar plates were incubated on the laboratory bench. The diameters of zones of inhibition were measured in millimeter with a ruler and recorded. This was repeated three times and average diameters were recorded.

\section{Determination of Minimum Inhibitory Concentration (MIC)}

The standard agar dilution protocol with doubling dilution was used. The extract was incorporated into nutrient agar at concentrations of $2.5 \mathrm{mg} / \mathrm{ml}$, to $20 \mathrm{mg} / \mathrm{ml}$. A control without the extract was also set up. $10 \mu \mathrm{l}$ each of the test organisms, previously diluted to give $10^{6} \mathrm{cfu} / \mathrm{ml}$ was used to inoculate the plates. These were incubated at 37 ${ }^{\circ} \mathrm{C}$ for 24 hours in the first instance, and for another 24 hours, before the results were recorded after observing for growth. The minimum inhibitory concentrations (MICs) of the extract for each test microorganism were regarded as the agar plate with the lowest concentrations without growth.

\section{RESULTS}

The results of the antibacterial activity of the ethanol extract of the aerial parts of Sida acuta (the extract) and some Standard strains of Staphylococcus aureus (NCTC 10788) and clinical isolates of Staphylococcus aureus, Bacillus subtilis and Streptococcus faecailis, are shown in Table 1 .The extract did not show any activity against Esherichia coli, Klebsiella pneumoniae, Pseudomonas aeruginosa and Candida albicans (Table 1).

The minimum inhibitory concentrations (MICs) of the extract against the test organisms are shown in Table 2. The MIC was $5.0 \mathrm{mg} / \mathrm{ml}$ against both the clinical isolates of Staphylococcus aureus, and against Standard strains of Staphylococcus aureus (NCTC 10788); $10 \mathrm{mg} / \mathrm{ml}$ against Streptococcus faecalis, and $10 \mathrm{mg} / \mathrm{ml}$ against Bacillus subtilis. The control did not produce any inhibitory activity against the organisms. The Gram negative organisms were not inhibited within the concentration range used in this study. The MIC of the crude extract for Candida albicans was not determined, since there was no 
Table 2: Minimum inhibitory concentrations (MICs) of the ethanol total extract of the aerial parts of Sida acuta against test organisms.

\begin{tabular}{lc}
\hline Organisms & $* \mathrm{MIC}(\mathrm{mg} / \mathrm{ml})$ \\
\hline Staphylococcus aureus (NCTC 10788) & 5.0 \\
Staphylococcus aureus & 5.0 \\
Streptococcus faecalis & 10 \\
Bacillus subtilis & 10 \\
Klebsiella pneumoniae & ND \\
Pseudomonas aeruginosa & ND \\
Esherichia coli & ND \\
Candida albicans & ND
\end{tabular}

* = Mean of 3 determinations; $N D=$ Not determined since there was no inhibitory activity

inhibitory activity. The zone of inhibition produced by $25 \mathrm{mg} / \mathrm{ml}$ of the extract was 21.4 $\mathrm{mm}$ as against $15.3 \mathrm{~mm}$ produced by $25 \mu \mathrm{g} / \mathrm{ml}$ of amoxycillin against the clinical isolates of Staphylococcus aureus. The zone of inhibition produced by $25 \mathrm{mg} / \mathrm{ml}$ of the extract against Standard strains of Staphylococcus aureus (NCTC 10788) was much lower $(16 \mathrm{~mm})$ when compared with that of the clinical isolates of Staphylococcus aureus (21.3 mm).

\section{DISCUSSION}

The ethanolic total crude extract of Sida acuta showed reasonable, comparable inhibitory activity against the Gram positive organisms; whereas there was no activity against any Gram negative bacteria. The bioactives of the extract which elicited antibacterial activity appeared to have preferential and specific activity against Gram positive bacteria. This observation could possibly justify the usefulness of the plant as earlier reported 5, 6,7. The extract presents narrow spectrum antibacterial activity since there was no activity against Gram negative bacteria, like Esherichia coli, Klebsiella pneumoniae, Pseudomonas aeruginosa and even Candida albicans - a fungus.

\section{CONCLUSION}

The ethanol extract of the aerial part of Sida acuta Burm.F.(Malvaceae) has activity against Gram positive bacteria. There was no activity against Candida albicans and hence does not possess antifungal activity. However, the activity shown against susceptible organisms, as observed in this study, would appear to justify the ethnomedicinal use in recipes for infections. Further studies would focus on isolation of the bioactives, biological and chemical characterization.

\section{ACKNOWLEDGEMENT}

The authors acknowledge the support of the University of Benin through research grant No. URPC/2006/6 for this preliminary investigation.

\section{REFERENCES}

1. Akobundu IO, Agyakwa C W. A Handbook of West African Weeds, ed 2, Intec Printers, 1998, p 348.

2. Kholkute SD, Munshi SR, Naik SD and Jathar $V S$. .Antifertility activities of indigenous plants, Sida carpinifolia and Podocarpus brevifolius, in female rats. Indian J Exp Biol 1978; 16: 696-698.

3. Holdsworth $D K$.Phytochemical survey of Medicinal Plants of the D'entrecasteaux Islands, Papua Sci New Guinea 2 1974; (2): 164-171.

4. Ramachandran $V S$ and Nair $N$ C. Ethnobotanical observations on Irulars of Tamil Nadu (India) $\mathrm{J}$ Econ Tax Bot 1981; 2: 183-190.

5. Barrett B .Medicinal plants of Nicaragua's Atlantic Coast. Econ. Bot 1994; 48:18-20.

6. Coee FG and Anderson G. Screening of medicinal plants used by the Garifuna of Eastern Nicaragua for Bioactive Compounds. J Ethnopharmacol 1996; 53: 29-50.

7. Pongpan $A$, Chumsri $P$ and Taworasate $T$. The antimicrobial activity of some Thai Medicinal Plants. Mahidol Univ J Pharm Sci 1982; 9 4: 88-91. 


\section{Akerele et al}

8. Goyal M M, Rani KK.Effects of natural products isolated from three species of Sida on some gram-positive and gram-negative bacteria. Journal of India Chem Soc 1988; 65 (1): 74-76.

9. Kumar, Bagchi G D, Darokar M P. Antibacterial activity observed in the Seeds of Some Coprophilous Plants. Int J Pharmacog 1997; 35 (3): 179-184.

10. Karou D, Savadogo A, Canini A, Yameogo, $S$, Montesano C, Simpore J, Colizzi V and Traore A .Antibacterial activity of the alkaloids from Sida acuta .Afr J Biotech 2005; 4 (12):1452-1457.
11. Ver-poorte R. Grand $L$ and Pousset J. Anti-infections and phytotherapies of the free Savanna of Senegal. J Ethnopharmacol 1988; 22 (1):25-31.

12. Irobi, O, Moo-Young $M$ and Anderson WA Antimicrobial activity of Annatto (Bixa orellana extract) .Int $\mathrm{J}$ Pharm 1996 ;34: 87-90.

13. Russel $A D$ and Fur $J R$.Antibacteria activity of a new chloroxylenol preparation containing ethylenediamine tetra-acetic acid. J. Appl. Bacteriol 1977; 43:253-260. 